Reprod. Nutr. Dévelop., 1988, 28 (5), 1267-1273

\title{
Characterization of regional proteins in tissues and fluids in the human epididymis
}

\author{
Henriette Roberte JUNERA, Marie-Françoise ALFONSI, Marcelle-Anne FAIN- \\ MAUREL, J. P. DADOUNE
}

Groupe d'Etude de la Formation et de la Maturation du Gamète Mâle (Laboratoires de Biologie cellulaire et d'Histologie).

45, rue des Saints-Pères, 75270 Paris Cedex 06. France.

Summary. The proteins of epididymal tissues and fluids recovered from five regions of the human epididymis were separated by polyacrylamide gel electrophoresis under denaturing conditions. Among the 60 peptides identified, eight appeared to be expressed solely in the epididymal duct when compared to serum and testis proteins. Three of these $(92,47$ and $24 \mathrm{Kd})$ showed a degree of regional specificity in fluids. The $92 \mathrm{Kd}$ peptide was found in the caput and proximal corpus, the $47 \mathrm{Kd}$ in the distal corpus and cauda and the $24 \mathrm{Kd}$ in the caput of the epididymis. Three of the specific epididymal proteins $(39,30$, $26 \mathrm{Kd}$ ) displayed a remarkable analogy to those found in man and monkey in other conditions and which are present at the sperm surface in the epididymis cauda.

\section{Introduction.}

As has been shown in several species of mammals, the acquisition by testicular spermatozoa of mobility, zona pellucida recognition ability and fertilizing capacity are mediated by proteins secreted by the epididymis (cf. Cooper, 1986). A similar process occurs in humans (Moore et al., 1983 ; Temple-Smith et al., 1985; Hinrichsen and Blaquier, 1980) and epididymal secretory antigens have been found in association with the acrosomal cap of mature spermatozoa (Tezón et al., 1985a). Using a model of cultured human epididymis from patients undergoing castration or epididymectomy, five androgen-dependent proteins were identified by their mobility relative to albumin in polyacrylamide gels, and their decreasing synthetic activity in the successive segments of the duct has been shown (Tezón et al., 1985b). On the other hand, four major fluid proteins common to samples from 10 men with epididymal obstructions were found by sodium dodecyl sulfate polyacrylamide gel electrophoresis (SDS-PAGE) (Jennings et al., 1987). The present preliminary investigation used SDS-PAGE to compare the proteins of human epididymal tissues and fluids from young men without any genital disorders along the entire duct.

Reprint requests to $H$. R. Junera.

Reproduction, Nutrition, Développement, $n^{\circ} 5 / 88-5$ 


\section{Materials and methods.}

Materials.

Epididymis and testis samples were obtained from two young men (21 and 26 years old) with proven brain death.

Each epididymal duct was dissected free from surrounding connective tissue and cut into five segments according to the subdivisions presented in Baumgarten et al. (1971) (fig. 1).

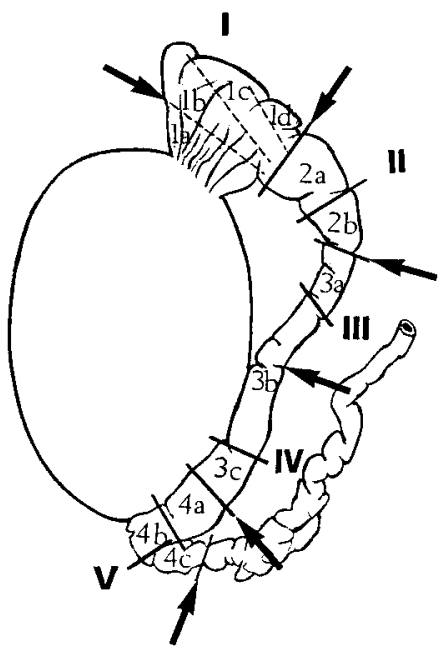

FIG. 1. - Schematic drawing of the human epididymis (modified from Baumgarten et al., 1971) subdivided by ligatures $(\rightarrow)$ into five anatomical segments : proximal caput (I), distal caput (II), proximal corpus (III), distal corpus (IV), cauda (V).

Preparation of samples.

The epididymal segments were sliced into small fragments $(3-4 \mathrm{~mm})$ which were separately suspended and shaken for $10 \mathrm{~min}$ in a phosphate saline buffer (pH 7.6) containing protease inhibitors (0.2 mM PMSF, $1 \%$ zymofren) and $4 \mathrm{mM}$ EDTA (100 $\mathrm{mg}$ tissue $/ 300 \mu \mathrm{l}$ buffer ; w/v).

Epididymal fluids were expressed and centrifuged (900 g, $10 \mathrm{~min}$ ) to separate spermatozoa. Tissues were removed, washed twice to obtain sperm-free tissues, and homogenized in $0.2 \%$ triton $X-100$ solution in the same buffer as above. Fluid and tissue homogenates were centrifuged twice (50 $000 \mathrm{~g}, 30 \mathrm{~min}$, $4{ }^{\circ} \mathrm{C}$ ) and stored $\left(-30^{\circ} \mathrm{C}\right)$ until analysis. Homogenates and fluids from the testes were collected and treated as the epididymal samples. For denaturation, 10-30 $\mu 1$ of each sample $(\simeq 50 \mu \mathrm{g})$ was mixed $(v / v)$ with the Laemmli sample buffer (12.5 mM Tris, $\mathrm{pH} 6.8,4 \%$ SDS, $20 \%$ glycerol, $5 \% \beta$-mercaptoethanol, $0.001 \%$ bromophenol blue as a dye) and boiled ( $3 \mathrm{~min})$. 
Protein concentration of samples was determined by the Bradford method (1976) with bovine serum albumin as standard protein.

\section{Polyacrylamide gel electrophoresis (PAGE).}

SDS-PAGE was performed in the Laemmli system (1970). Electrophoresis were carried out on vertical slab $15 \%$ gels at a constant current $(20 \mathrm{mAmp}$. per gel plate, $\simeq 20^{\circ} \mathrm{C}$ for 6 hours). Proteins were stained either with Coomassie brillant blue solution or a modified silver stain method (from Morrissey, 1981).

Molecular weight (MW) characterization was performed by comparing the relative mobility of comigrating proteic standards (Pharmacia, low molecular weight protein calibration kit).

\section{Results.}

Separation of proteins from homogenates and luminal fluids of the five successive segments (proximal and distal caput, proximal and distal corpus, cauda) of human epididymis revealed the presence of approximately 60 peptides with widely varying molecular weights ( 180 to $10 \mathrm{Kd}$ ), and major bands ranging from 94 to $25 \mathrm{Kd}$ (fig. 2).

Eight major bands found in tissues and fluids were not matched by comparable bands from human serum and testis after silver reaction. Five of these $(39,33,30,26$ and $25 \mathrm{Kd})$ were detected in all the epididymal segments with the same staining intensity whereas the three others, present in both tissues and fluids $(92,47$ and $24 \mathrm{Kd})$, only showed a degree of regional specificity in fluids. The 92 and $24 \mathrm{Kd}$ peptides were not expressed in the fluids of the cauda $(92 \mathrm{Kd})$ or the corpus and cauda $(24 \mathrm{Kd})$ whereas the $47 \mathrm{Kd}$ was only present in the distal corpus and cauda fluids (table 1 ).

On the other hand, four peptides which migrated similarly with testicular peptides showed regional differences. The $43 \mathrm{Kd}$ peptide was only expressed in the tissues and fluids of the caput and proximal corpus. The staining intensity of the major epithelial and luminal band at $41 \mathrm{Kd}$ increased along the duct. The minor bands at $19 \mathrm{Kd}$ and $15.5 \mathrm{Kd}$ which were present in the caput tissue were detected in the fluids of the five epididymal segments.

\section{Discussion.}

Among the 60 peptides separated after SDS-PAGE of soluble proteins from the five epididymal regions, eight peptides appeared to be expressed solely in the epididymal duct when compared to serum and testis proteins. Some had a remarkable analogy with previous data obtained in man and monkey. With respect to their approximately similar molecular weight, the 39 and $30 \mathrm{Kd}$ peptides expressed in the five epididymal segments might be similar to the androgeninduced 38 and $29 \mathrm{Kd}$ proteins identified in cultured human caput and corpus tubules (Tezón et al., 1985b). The 38-39 Kd peptide might correspond to the $37 \mathrm{Kd}$ sialoprotein which has been found at the surface of human spermatozoa from the epididymis distal part (Dacheux et al., 1984). 

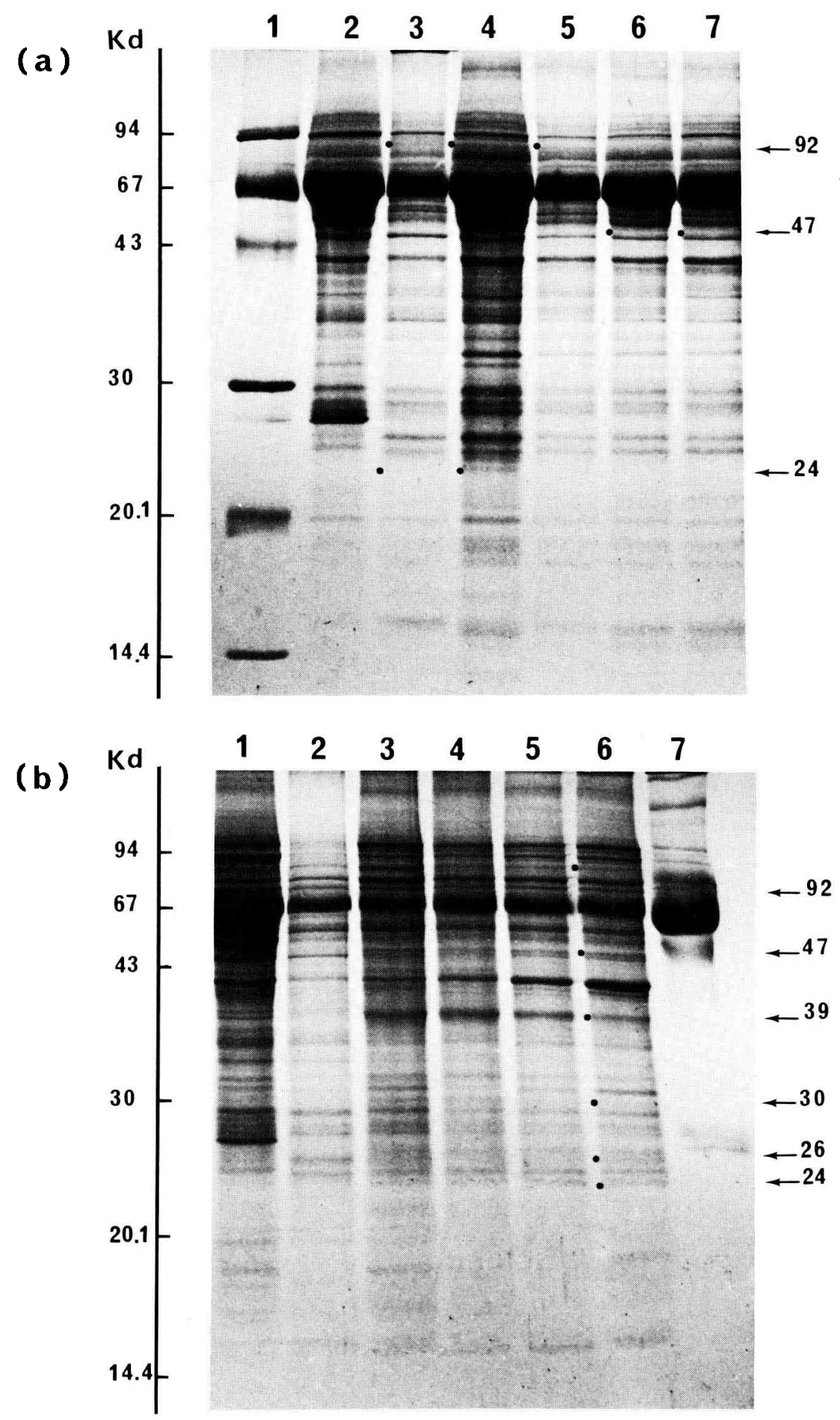
TABLE 1

Regional differences in the tissues $(\mathrm{T})$ and fluids $(\mathrm{F})$ from the five epididymal segments ( 1 : proximal caput, II : distal caput, III : proximal corpus, IV : distal corpus, V : cauda) analyzed by $15 \%$ SDS-PAGE. $(+)$ : presence of band, $(-)$ : absence of band, $( \pm)$ : variable width or staining intensity, $\left(^{*}\right)$ : specific epididymal bands.

\begin{tabular}{|c|c|c|c|c|c|c|}
\hline MW & & 1 & II & III & IV & V \\
\hline $92^{*}$ & $\begin{array}{l}\mathrm{T} \\
\mathrm{F}\end{array}$ & $\begin{array}{c}+ \\
++\end{array}$ & $\begin{array}{c}+++ \\
++\end{array}$ & $\begin{array}{l}+ \\
\pm\end{array}$ & + & $\begin{array}{l}+ \\
-\end{array}$ \\
\hline $47^{*}$ & $\begin{array}{l}T \\
F\end{array}$ & - & \pm & + & $\begin{array}{l}+ \\
+\end{array}$ & $\begin{array}{l}+ \\
+\end{array}$ \\
\hline 43 & $\begin{array}{l}T \\
F\end{array}$ & $\begin{array}{l}+ \\
-\end{array}$ & + & + & \pm & \pm \\
\hline 41 & $\begin{array}{l}T \\
F\end{array}$ & + & $\begin{array}{l}+ \\
+\end{array}$ & $\begin{array}{l}+ \\
+\end{array}$ & $\begin{array}{l}++ \\
++\end{array}$ & $\begin{array}{c}+++ \\
++\end{array}$ \\
\hline $24^{*}$ & $\begin{array}{l}T \\
F\end{array}$ & $\begin{array}{l}+ \\
\pm\end{array}$ & $\begin{array}{l}+ \\
+\end{array}$ & + & + & $\begin{array}{l}+ \\
-\end{array}$ \\
\hline 19 & $\begin{array}{l}T \\
F\end{array}$ & $\begin{array}{l}+ \\
\pm\end{array}$ & $\begin{array}{l}+ \\
+\end{array}$ & $\begin{array}{l}- \\
+\end{array}$ & $\begin{array}{l}- \\
+\end{array}$ & $\begin{array}{l}- \\
+\end{array}$ \\
\hline 15.5 & $\begin{array}{l}T \\
F\end{array}$ & + & $\begin{array}{l}+ \\
+\end{array}$ & $\overline{+}$ & $\overline{+}$ & $\begin{array}{l}- \\
+\end{array}$ \\
\hline
\end{tabular}

On the other hand the $26 \mathrm{Kd}$ protein, found in the five epididymal segments, could be assimilated to an electrophoretically comparable peptide of $27 \mathrm{Kd}$ which has been detected in chimpanzee epididymal fluid. A recent work suggests that this peptide, which is absorbed at the sperm surface during maturation and is removed from the surface of mature sperm in the female reproductive tract, affects sperm motility (Young et al., 1987). The binding of a $26 \mathrm{Kd}$ fluid component to the plasma membrane of cauda epididymal sperm has also been demonstrated in the rat, using immunoelectron microscopy, and correlated with major changes in the motility pattern of sperm (Olson et al., 1987). The apparent differences in molecular weights among components involved in sperm motility could be accounted for if these macromolecules are glycoproteins, since glycoproteins have different molecular weights when analyzed on gels composed of different amounts of polyacrylamide (Segrest et al., 1971).

The regional differences found between the five epididymal segments were revealed by variations in band staining intensity. The abundance of the $92 \mathrm{Kd}$ peptide in the caput and the $41 \mathrm{Kd}$ peptide in the distal corpus and cauda were

FIG. 2. - Coomassie blue stained $15 \%$ SDS-PAGE of human epididymal fluids (a) and tissue homogenates (b) from different anatomical segments compared to low molecular weight standards (lane 1a) and testicular extract and fluid (lanes 2a, 1b), proximal (lanes $3 \mathrm{a}, 2 \mathrm{~b}$ ) and distal (lanes 4a, 3b) caput, proximal (lanes 5a, 4b) and distal (lanes 6a, 5b) corpus, cauda (lanes 7a, 6b) and human serum (lane 7b).

Proteins of interest are indicated by arrows with their respective molecular weight (Kd). 
particularly noticeable. In addition, the caput segment was characterized by the presence of two cytosolic peptides : 19 and $15.5 \mathrm{Kd}$. Thus, the present investigation points out clearly that the human epididymis is made up of two distinct entities, the caput on the one hand, the corpus and cauda on the other hand, as has been previously shown in mouse epididymis (Abou-Hailla and Fain-Maurel, 1984 ; Fain-Maurel et al., 1988 ; Mboungou et al., 1988).

$5^{e}$ Congrès de la Société d'Andrologie de langue française, Paris, décembre 1987.

Résumé. Caractérisation des protéines régionales dans les tissus et les fluides de l'épididyme humain.

Les protéines tissulaires et luminales de l'épididyme humain, subdivisé en 5 régions anatomiques, ont été caractérisées par électrophorèse en gel de polyacrylamide en conditions dénaturantes. Parmi la soixantaine de peptides qui ont été ainsi séparés, huit, non détectés dans le sérum et les extraits testiculaires, apparaissent spécifiques de l'épididyme. Trois d'entre eux $(92,47$ et $24 \mathrm{Kd})$ montrent une spécificité régionale dans les fluides ; le peptide de $92 \mathrm{Kd}$ s'exprime dans la tête et le corps proximal, celui de $47 \mathrm{Kd}$ dans le corps distal et la queue, celui de $24 \mathrm{Kd}$ dans la tête. Parmi les protéines spécifiques de l'épididyme, trois d'entre elles $(39,30,26 \mathrm{Kd})$ présentent une analogie avec des protéines identifiées, dans des conditions expérimentales différentes, à la surface des spermatozoïdes de la queue de l'épididyme chez l'homme et le singe.

\section{References}

ABOU-HAÏLA A., FAIN-MAUREL M.-A., 1984. Regional differences of proximal part of mouse epididymis. Morphological and histochemical characterization. Anat. Rec., 209, 197-208.

BAUMGARTEN H. G., HOLSTEIN A. F., ROSENGREN E., 1971. Arrangement, ultrastructure, and adrenergic innervation of smooth musculature of the ductuli efferentes, ductus epididymis and ductus deferens of man. Z. Zel/forsch., 120, 37-79.

BRADFORD M. M., 1976. A rapid sensitive method for the quantitation of microgram quantities of protein utilizing the principle of protein-dye binding. Ann. Biochem., 72, 248-254.

COOPER T. G., 1986. The epididymis, sperm maturation and fertilization. Springer Verlag Berlin.

DACHEUX J. L., CHEVRIER C., DESMEE A., LANNEAU M., JOUANNET P., ZEPHIR D., LANSON Y., 1984. Evolution de la mobilité et des protéines de surface des spermatozoïdes humains lors de leur passage dans l'épididyme. J. Urol., 90, 582-583.

FAIN-MAUREL M.-A., ABOU-HAILA A., DADOUNE J. P., 1988. Organization of the internal membrane system in the principal cells of the mouse epididymis after osmium impregnation. Reprod. Nutr. Develop., 88,1237-1250.

HINRICHSEN M. J., BLAQUIER J. A., 1980. Evidence supporting the existence of sperm maturation in the human epididymis. J. Reprod. Fert., 60, 291-294.

JENNINGS M. G., TEMPLE-SMITH P. D., SOUTHWICK G. J., NAUADU P. L., BAKER H. W. G., 1987. Patterns of human epididymal fluid proteins on polyacrylamide gel electrophoresis. Int. J. Androl., 10, 441-446.

LAEMMLI U. K., 1970. Cleavage of structural proteins during the assembly of the head of bacteriophage T4. Nature, 227, 680-685.

MBOUNGOU J. R., JUNERA H. R., DADOUNE J. P., FAIN-MAUREL M.-A., 1988. Characterization and hormonal regulation of tissue and fluid proteins in the mouse epididymis. Reprod. Nut. Develop., 28,1275-1282.

MOORE H. D. M., HARTMANN T. D., PRYOR J. P., 1983. Development of the oocyte-penetrating capacity of spermatozoa in the human epididymis. Int. J. Androl., 6, 310-318. 
MORRISSEY J. H., 1981. Silver stain for proteins in polyacrylamide gels : a modified procedure with enhanced uniform sensitivity. Anal. Biochem., 117, 307-310.

OLSON G. E., LIFSICS M. R., WINFREY V. P., RIFKIN J. M., 1987. Modification of the rat sperm flagellar plasma membrane during maturation in the epididymis. J. Androl., 8, 129-147.

SEGREST J. P., JACKSON R. L., ANDREW E. P., MARCHESI V. T., 1971. Human erythrocyte membrane glycoproteins, a re-evaluation of the molecular weight as determined by SDS-polyacrylamide gel electrophoresis. Biochem. Biophys. Res. Commun., 44, 390-395.

TEMPLE-SMITH P. D., SOUTHWICK G. J., YATES C. A., 1985. Human pregnancy by in vitro fertilization (IVF) using sperm aspirated from the epididymis. J.J.V.F. Embryo transplants, 2 , 119-122.

TEZÓN J. G., RAMElla E., CAMEO M. S., VASQuez M. H., BLAQuieR J. A., 1985a. Immunochemical localization of secretory antigens in the human epididymis and their association with spermatozoa. Biol. Reprod., 32, 591-597.

TEZON J. G., VASQUEZ M. H., PIÑEIRO L., DE LARMINAT M. A., BLAQUIER J.A., 1985b. Identification of androgen-induced proteins in human epididymis. Biol. Reprod., 32, 584-590.

YOUNG L. G., GOULD K. G., HINTON B. T., 1987. Changes in binding of a 27-Kilodalton chimpanzee cauda epididymal protein glycoprotein component to chimpanzee sperm. Gamete Res., 18, 163-178. 